\title{
Effect of the CeZrNd mixed oxide synthesis method in the catalytic combustion of soot.
}

\author{
Jorge González Mira, Verónica Rico Pérez, Agustín Bueno-López*. \\ Department of Inorganic Chemistry. University of Alicante, Ap.99, E-03080 \\ Alicante (Spain). \\ *Corresponding author: email: agus@ua.es;Tel. +34 600948665; Fax.+34 965903454
}

\begin{abstract}
$\mathrm{Ce}_{0.64} \mathrm{Zr}_{0.27} \mathrm{Nd}_{0.09} \mathrm{O}_{\delta}$ mixed oxides have been prepared by three different methods (nitrates calcination, coprecipitation and microemulsion), characterized by $\mathrm{N}_{2}$ adsortion, XRD, $\mathrm{H}_{2}$-TPR, Raman spectroscopy and XPS, and tested for soot combustion in $\mathrm{NOx} / \mathrm{O}_{2}$. The catalyst prepared by microemulsion method is the most active one, which is related to its high surface area $\left(147 \mathrm{~m}^{2} / \mathrm{g}\right)$ and low crystallite size $(6 \mathrm{~nm})$, and the lowest activity was obtained with the catalyst prepared by coprecipitation $\left(74 \mathrm{~m}^{2} / \mathrm{g} ; 9 \mathrm{~nm}\right)$. The catalyst prepared by nitrates precursors calcination is slightly less active to that prepared by microemulsion but the synthesis procedure is very straightforward and surfactants or other chemicals are not required, being very convenient for scaling up and practical utilization. The high activity of the catalyst prepared by nitrates calcination can be attributed to the better introduction of $\mathrm{Nd}$ cations into the parent ceria framework than on catalysts prepared by coprecipitaion and microemulsion, which promotes the creation of more oxygen vacancies.
\end{abstract}

Keywords: Diesel soot; ceria-zirconia catalyst; neodymium-ceria catalyst; mixed oxide catalyst; ceria. 


\section{1.- Introduction.}

Mixed oxide catalysts of ceria doped with different cations are being investigated for diesel soot combustion, in order to replace current Pt-based formulations by some other cheaper active phases. A number of different ceriabased mixed oxides have been investigated, like ceria doped with La [1-5], Zr $[4,6-12], \operatorname{Pr}[2,3,5], \mathrm{Sm}[2,3], \mathrm{Tb}[2], \mathrm{Y}[3], \mathrm{Mn}[13-15], \mathrm{Hf}[8], \mathrm{Nb}[16], \mathrm{Nd}[5$, 17], $\mathrm{Ru}$ [18], $\mathrm{Zn} \mathrm{[19]} \mathrm{or} \mathrm{Gd} \mathrm{[20].} \mathrm{Among} \mathrm{all} \mathrm{those} \mathrm{ceria} \mathrm{dopants} \mathrm{Zr}$ is the most studied, maybe because ceria-zirconia mixed oxides have used for more than 30 years in Tree Way Catalysts [21].

Nevertheless, there are only few examples of reported studies dealing with ternary mixed oxide soot combustion catalysts consisting of ceria-zirconia doped with a third cation, and there is not a general agreement about the benefit of loading a third dopant together with $\mathrm{Ce}$ and $\mathrm{Zr}$. Aneggi et all. [2] studied ternary ceria-zirconia catalysts doped with La, Pr, Sm or Tb cations for soot combustion in air and did not observed the positive effect of the third cation. On the contrary, Dulgheru and Sullivan [5] have recently studied La, Nd or $\operatorname{Pr}$ doped ceria-zirconia for soot combustion in a $\mathrm{NOx} / \mathrm{O}_{2} / \mathrm{N}_{2}$ gas mixture, concluding that the incorporation of one of these three cations together with $\mathrm{Ce}$ and $\mathrm{Zr}$ has a positive effect on the catalytic activity. We have also studied $\mathrm{Y}$ doped [22] and Nd-doped [17] ceria-zirconia soot combustion catalysts and $\mathrm{Y}$ doping showed a little improvement on the activity while Nd-doping provided better results. It was observed for ternary Ce-Zr-Nd mixed oxides that Zr doping improved the thermal stability and redox properties of ceria and $\mathrm{Nd}$ doping improved additional the redox properties by creation of vacant sites [17]. 
Ternary Ce-Zr-Nd mixed oxides were also studied by Wang et al. [23] as Pd support in Three Way Catalysts, and it was also concluded that $\mathrm{Nd}$ improved the reducibility and redox behavior of ceria-zirconia mixed oxides, leading to the better catalytic activity in wider air/fuel ratios.

In a previous study, the Ce-Zr-Nd mixed oxide composition was optimized for the simultaneous oxidation of soot, hydrocarbons and $\mathrm{CO}$ in simulated diesel exhaust conditions, and the best formulations were $\mathrm{Ce}_{0.73-\mathrm{x}} \mathrm{Zr}_{0.27} \mathrm{Nd}_{\mathrm{x}} \mathrm{O}_{\delta}$ with $0.01 \leq \mathrm{x} \leq 0.09$ [24]. For this reason, $\mathrm{Ce}_{0.64} \mathrm{Zr}_{0.27} \mathrm{Nd}_{0.09} \mathrm{O}_{\delta}$ catalysts have been selected for the current study.

On the other hand, it is known that the synthesis method of ceria-zirconia mixed oxides significantly affects their physicochemical features and catalytic behavior. For instance, high surface area ceria-zirconia solid solutions (BET surface area $>200 \mathrm{~m}^{2} / \mathrm{g}$ ) were prepared by Terribile et at. [25] following a surfactant-assisted synthesis method, homogeneous ceria-zirconia mixed oxides with narrow particle-size distribution were prepared by Stark et al. [26] by flame-spray synthesis, Yu et al. [27] prepared nanoporous ceria-zirconia by means of a sonochemical method and Crocker et al. [28] obtained ceria-zirconia with $148 \mathrm{~m}^{2} / \mathrm{g}$ surface area by application of carbon templating. Some other straightforward methods have been widely studied for ceria-zirconia catalysts preparation, like coprecipitation [29] or direct calcination of a nitrate precursors mixture [30] among others. The catalytic combustion of soot was also studied in our group with $\mathrm{Ce}_{0.76} \mathrm{Zr}_{0.24} \mathrm{O}_{2}$ mixed oxides prepared by different methods, including coprecipitation with $\mathrm{NH}_{3}$, physical mixture of nitrates + calcination, physical mixture of oxides + calcination, solid combustion synthesis (SCS) with 
urea, citrate complexation route, reversed microemulsion and activated carbon fiber templating. It was concluded that both the BET surface area and the surface concentration of $\mathrm{Ce}$ and $\mathrm{Zr}$ on the catalyst surface affected the combustion of soot, and both features were strongly affected by the synthesis

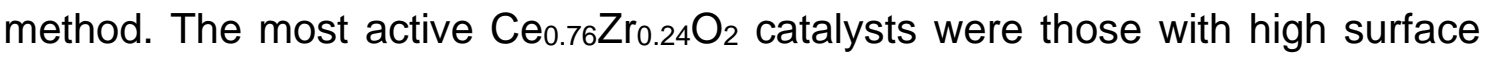
area and $\mathrm{Ce}$ and $\mathrm{Zr}$ surface concentrations near the nominal values, that is, those forming homogeneous solid solutions [31].

However, the effect of the synthesis method of ternary Ce-Zr-Nd mixed oxides on the catalytic combustion of soot has not been reported so far, and this is the goal of the current study. According to our previous experience, three methods have been compared: calcination of a $\mathrm{Ce}+\mathrm{Zr}$ nitrate precursors mixture, coprecipitation and reversed microemulsion. Usually, the microemulsion methods allow obtaining high surface area oxides with good catalytic properties, the coprecipitation method is probably the most used synthesis route for ceria-zirconia mixed oxide catalysts because it is easy and the catalytic results are usually not bad and the nitrates calcination method is one of the simplest preparation procedures.

\section{2.- Experimental details.}

\subsection{Catalysts preparation.}

Three $\mathrm{Ce}_{0.64} \mathrm{Zr}_{0.27} \mathrm{Nd}_{0.09} \mathrm{O}_{\delta}$ mixed oxide catalysts have been prepared, which are referred to as "nitrates calcination", "coprecipitation" and "microemulsion". The metal precursors used were $\mathrm{Ce}\left(\mathrm{NO}_{3}\right)_{3} \cdot 6 \mathrm{H}_{2} \mathrm{O}$ (Sigma Aldrich, 99\%), $\mathrm{Nd}\left(\mathrm{NO}_{3}\right)_{3} \cdot 6 \mathrm{H}_{2} \mathrm{O}$ (Aldrich, 99.9\%) and $\mathrm{ZrO}\left(\mathrm{NO}_{3}\right)_{2} \cdot \mathrm{xH}_{2} \mathrm{O}($ Fluka, $\mathrm{x} \approx$ 6). The preparation procedures consisted of: 
- "nitrates calcination" catalyst: The required amounts of each metal precursor were thoroughly mixed in a mortar and calcined at $500{ }^{\circ} \mathrm{C}$ for 2 hours (heating rate $10^{\circ} \mathrm{C}$ ).

- "coprecipitation" catalyst: The required amounts of each metal precursor were dissolved in water and an ammonia solution was dropped until $\mathrm{pH}$ 9. The precipitates were dried overnight at $110{ }^{\circ} \mathrm{C}$ in air and calcined at $450^{\circ} \mathrm{C}$ for 1 hour (heating rate $10^{\circ} \mathrm{C}$ ).

- "microemulsion" catalyst: the required amounts of each precursor were dissolved in water (130 $\mathrm{g}$ of all precursors in the proper ratio per liter of water) and a microemulsion in n-heptane was prepared, also adding Triton X-100 and hexanol. The water : n-heptane : Triton X-100 : hexanol weight ratio was $1: 5.7: 1.9: 1.5$. A similar microemulsion was prepared but with tetramethylammonium hydroxide $(340 \mathrm{~g} / \mathrm{L})$ instead of the metal precursors. Both microemulsions were mixed, stirred for 24 hours and, after precipitation, were centrifuged and the liquid was decanted. The solids obtained were washed with ethanol, dried overnight at $110^{\circ} \mathrm{C}$ and calcined at $450^{\circ} \mathrm{C}$ for 1 hour (heating rate $10^{\circ} \mathrm{C}$ ).

\subsection{Catalytic tests.}

Soot combustion experiments were carried out in a tubular quartz reactor with soot catalysts mixtures (20 mg of soot $+80 \mathrm{mg}$ of catalyst $+300 \mathrm{~g} \mathrm{SiC}$ ) prepared with a spatula in the so-called loose contact mode in order to obtain results with practical meaning [32]. Specific NDIR-UV gas analyzers for CO, $\mathrm{CO}_{2}, \mathrm{NO}, \mathrm{NO}_{2}$ and $\mathrm{O}_{2}$ (Fisher-Rosemount, models BINOS 100, 1001 and 1004) were used for gas monitoring. The model soot used was a carbon black 
by Evonik-Degussa $\mathrm{GmbH}$ (Printex $U$ ) and the gas mixture composition was $500 \mathrm{ppm} \mathrm{NO} / 5 \% \quad \mathrm{O}_{2} / \mathrm{N}_{2}\left(500 \mathrm{ml} / \mathrm{min} ; \mathrm{GHSV}=30000 \mathrm{~h}^{-1}\right)$. The reactor temperature was raised from room temperature until $700^{\circ} \mathrm{C}$ at $10^{\circ} \mathrm{C} / \mathrm{min}$.

\subsection{Catalysts characterization.}

$\mathrm{N}_{2}$ adsorption-desorption isotherms were carried out with the catalysts at $-196{ }^{\circ} \mathrm{C}$ in an automatic volumetric system (Autosorb-6, Quantachrome) after outgassing the catalysts at $150{ }^{\circ} \mathrm{C}$ for 4 hours. The specific surface area and the pore sizes distribution were determined by the Brunauer, Emmett and Teller (BET) and Barret, Joyner and Halenda (BJH) methods, respectively.

X-Ray difrractograms were recorded in a Bruker D8 advance device, (CuKa radiation with $\lambda=0.15418 \mathrm{~nm}$ ) between $10^{\circ}$ and $80^{\circ}(2 \theta)$ and a step size of $0.05^{\circ}$. The crystal size was estimated with the Williamson-Hall's method [33]:

$$
\beta_{\text {Total }}=\beta_{\text {Size }}+\beta_{\text {Strain }}=\frac{0.9 \cdot \lambda}{D \cdot \operatorname{Cos} \theta}+\frac{4 \cdot(\Delta d) \cdot \operatorname{Sin} \theta}{d \cdot \operatorname{Cos} \theta} \quad \text { (Williamson-Hall's equation) }
$$

where $\beta_{\text {Total }}$ is the full width half maximum of the XRD peak, $\lambda$ is the incident $x-$ ray wave length, $\theta$ is the position of the peaks, $D$ is the crystallite size, and $\Delta d$ is the difference of the $d$ spacing corresponding to a typical peak. A plot of $\beta_{\text {Total }} \cdot \cos \theta$ versus $4 \cdot \sin \theta$ yields the crystal size from the intercept value.

Temperature programed reductions with $\mathrm{H}_{2}\left(\mathrm{H}_{2}-\mathrm{TPR}\right)$ were carried out in a thermobalance TG-DTA (TGA/SDTA851and/LF/1600 from METTLER TOLEDO) coupled to a Mass Spectrometer (PFEIFFER VACUUM THERMOSTAR GSD301T quadrupole). $20 \mathrm{mg}$ of fresh catalyst, $100 \mathrm{ml} / \mathrm{min}$ of a $10 \% \mathrm{H}_{2} / \mathrm{Ar}$ flow and a heating rate of $10^{\circ} \mathrm{C} / \mathrm{min}$ were used. The reduction of the 
mixed oxide catalysts was followed by the water released above $250{ }^{\circ} \mathrm{C}(\mathrm{m} / \mathrm{z} 18$ signal).

Raman spectra were obtained in a Bruker RFS 100/S Fourier Transform Spectrometer (Nd-YAg laser source of $1064 \mathrm{~nm}$ ).

XPS analysis of the catalysts was performed in a K-ALPHA Thermo Scientific device, using Al-Ka radiation (1486.6 eV) monochromatized by a twin crystal monochromator, yielding a focused X-ray spot with a diameter of 400 $\mu \mathrm{m}$, at $3 \mathrm{~mA} \times 12 \mathrm{kV}$. The binding energy (BE) and kinetic energy (KE) scales were adjusted by setting the $\mathrm{C} 1 \mathrm{~s}$ transition at $284.6 \mathrm{eV}$, and the energy regions analyzed were those corresponding to C1s (279-298 eV), O1s (525-545 eV), Ce3d (870-930 eV), Zr3d (174-194 eV) and Nd3d (975-1050 eV).

\section{3.- Results and discussion.}

\subsection{Catalytic tests.}

Figure 1 shows the soot conversion profiles obtained in the uncatalyzed and catalyzed reactions and Table 1 compiles the $\mathrm{CO}_{2}$ yield, which was calculates as the ratio between the total $\mathrm{CO}_{2}$ mole evolved with regard to the $\mathrm{CO}+\mathrm{CO}_{2}$ sum. It has to be mentioned that the decrease of the NOx level during the reactions was less than $10 \%$ in all experiments.

As expected, all these three $\mathrm{Ce}_{0.64} \mathrm{Zr}_{0.27} \mathrm{Nd}_{0.09} \mathrm{O}_{\delta}$ catalysts lower the soot combustion temperature with regard to the uncatalyzed reaction and increase the $\mathrm{CO}_{2}$ yield from $36 \%$ to more than $90 \%$. The sequence of activity observed is:

microemulsion $>$ nitrates calcination $>$ coprecipitation $>>$ No catalyst 
The catalyst prepared by microemulsion method is the most active, which is not surprising, and the lowest activity was obtained with the catalyst prepared by coprecipitation. The catalytic behavior of the mixed oxide catalyst prepared by just calcination of the nitrates precursors mixture is very promising because, in spite of the activity is slightly lower to that of the catalyst prepared by microemulsion, the synthesis procedure is very straightforward and surfactants or other chemicals are not required. It is therefore very convenient for scaling up and practical utilization.

\subsection{Structural characterization of the catalysts by $X R D$ and $N_{2}$ adsorption.}

The catalytic activity trend observed in Figure 1 is properly explained by the characterization results. Figure 2 shows the $\mathrm{N}_{2}$ adsortion-desorption isotherms at $-196{ }^{\circ} \mathrm{C}$ of the $\mathrm{Ce}_{0.64} \mathrm{Zr}_{0.27} \mathrm{Nd}_{0.09} \mathrm{O}_{\delta}$ catalysts, Table 2 compiles the specific BET surface areas and Figure 3 shows the pore size distributions determined with the $\mathrm{BJH}$ method. All catalysts present type IV isotherms, according to the IUPAC classification, which are characteristic of mesoporous solids. The pore size distributions confirm that most pores are larger than $2 \mathrm{~nm}$, lying on the mesoporous range.

The highest BET surface area (see Table 2) was obtained by the microemulsion method $\left(147 \mathrm{~m}^{2} / \mathrm{g}\right)$ and most pores are in the 2-6 $\mathrm{nm}$ range of sizes for this catalyst. The highest activity for soot combustion of this catalyst can be related to its high surface area (and small particle size, as shown below), which favors the contact with the soot particles. The important role of the specific surface area of ceria catalysts in the combustion of soot is well 
known $[1,2,22]$, but it is also known that it is not the only factor affecting the activity $[2,22]$. It was demonstrated for ceria-zirconia mixed oxides that the surface composition also plays a critical role on the activity [22], and the XPS characterization of the Ce-Zr-Nd catalysts prepared in this study and discussed afterwards supports this conclusion.

The BET surface area of catalysts prepared by the nitrates calcination and coprecipitation methods are much lower $\left(70-74 \mathrm{~m}^{2} / \mathrm{g}\right)$ to that of the catalyst prepared by microemulsion, as expected, and some differences are noticed in the pore size distributions. The catalyst prepared by coprecipitation presents a narrow pore size distribution with most pores in the $2-4 \mathrm{~nm}$ range while the catalyst prepared by nitrates calcination shows a wide distribution, with most pores between 2 and $9 \mathrm{~nm}$.

The catalysts characterization by XRD is consistent with the $\mathrm{N}_{2}$ adsorption-desorption results. All X-ray diffractograms compiled in Figure 4 show the reflexions of the typical cubic fluorite structure of ceria [25], and evidences of segregated phases are not obvious in these diffraction patterns. Nevertheless, evidences of a certain segregation of a $\mathrm{Zr}$-rich tetragonal phase were previously obtained in Ce-Zr-Nd mixed oxides prepared by coprecipitation [24], probably because a different X-Ray diffractometer with higher resolution was used. For this reason, and taking also into account the experimental evidences provided by other techniques and discussed below, the segregation of different phases cannot be ruled out in the current study.

The catalyst preparation method significantly affected the position, intensity and broadening of the XRD peaks of Figure 4, and these differences are evidenced in the crystallite size and cell parameters compiled in Table 2. 
The cell parameters obtained for all catalysts (see Table 2) are around the value usually obtained with pure ceria $(0.5411 \mathrm{~nm}$; [17]) but it is difficult in this case to analyze the differences among samples into detail because they are in the order of the experimental error $( \pm 0.0025 \mathrm{~nm})$. However, Raman spectroscopy characterization discussed below seems more appropriate in this case, and shows differences in the incorporation of the $\mathrm{Zr}$ and Nd cations into the parent ceria lattice, in spite of the XRD results hardly show such differences.

The smallest crystallite size $(6 \mathrm{~nm}$; see Table 2$)$ corresponds to the mixed oxide prepared by microemulsion, which is consistent with the highest BET specific surface area of this catalyst $\left(147 \mathrm{~m}^{2} / \mathrm{g}\right)$, and the crystallite size of the catalyst prepared by coprecipitation is slightly higher $(9 \mathrm{~nm})$, being also consistent with the lower BET specific surface area of this mixed oxide (74 $\mathrm{m}^{2} / \mathrm{g}$ ). The largest crystallite size corresponds to the catalyst prepared by nitrates calcination $(37 \mathrm{~nm})$, in spite of the BET specific surface area $\left(70 \mathrm{~m}^{2} / \mathrm{g}\right)$ is quite similar to that of the catalyst prepared by coprecipitation. These differences can be explained taking the pore size distributions into account, since while the coprecipitation catalyst presents a narrow pore size distribution the nitrates calcination catalyst shows a much wider distribution. These XRD and pore size distribution results suggest that both the microemulsion and coprecipitation catalysts consist of a quite homogeneous agglomeration of particles (the former being smaller than the latter) while the nitrates calcination catalyst is expected to consist of a mixture of particles with different size.

\subsection{Catalysts reducibility studied by $\mathrm{H}_{2}-T P R$.}


The $\mathrm{H}_{2}$-TPR profiles included in Figure 5 are in agreement with these morphologies. The $\mathrm{H}_{2}$-TPR profiles of doped ceria typically consist of a broad band centered around $500-550^{\circ} \mathrm{C}$ with a shoulder or tail at higher temperatures in some cases [34, 35], and all profiles of Figure 5 show this shape. In this type of experiments the catalyst surface is reduced first at mild temperature, and once surface oxygen is depleted bulk oxygen is consumed. If oxygen mobility into the lattice is poor the surface and bulk reduction peaks appear clearly split, but this is not the case of the catalysts under study. A single peak is obtained for the microemulsion catalyst, which is not surprising because, for solids with very low particle size (6 $\mathrm{nm}$ is the crystallite size of the microemulsion catalyst; see table2), there is a minor difference in the energies required for surface and bulk reductions. On the contrary, a certain shoulder is observed above $650^{\circ} \mathrm{C}$ in the catalyst prepared by nitrates calcination due to the reduction of the catalyst bulk, and this is consistent with the presence of large crystals on this catalyst.

3.4. Analysis of $\mathrm{Zr}$ and $\mathrm{Nd}$ doping into the ceria lattice by Raman spectroscopy and XPS.

Information about the incorporation of the $\mathrm{Zr}$ and $\mathrm{Nd}$ cations into the parent ceria framework is obtained from the Raman spectra of Figure 6. The three $\mathrm{Ce}_{0.64} \mathrm{Zr}_{0.27} \mathrm{Nd}_{0.09} \mathrm{O}_{\delta}$ catalysts show an intense band around $465 \mathrm{~cm}^{-1}$ characteristic of the cubic fluorite structure of ceria [36], which is in accordance with the X-ray diffractograms (Figure 4), and another band or shoulder at 560$590 \mathrm{~cm}^{-1}$ that can be attributed to oxygen vacant sites created on the mixed oxide lattice [37]. The actual position of the main ceria band is in fact lower than 
$465 \mathrm{~cm}^{-1}$ for all $\mathrm{Ce}_{0.64} \mathrm{Zr}_{0.27} \mathrm{Nd}_{0.09} \mathrm{O}_{\delta}$ catalysts, which is the typical value for plane ceria. The shift of this band towards Raman shifts higher than $465 \mathrm{~cm}^{-1}$ occurs because of doping with cations smaller than $\mathrm{Ce}^{4+}\left(\right.$ like $\mathrm{Zr}^{4+}$ ) while the shift towards lower Raman shifts occurs due to doping with larger cations (like $\mathrm{Nd}^{3+}$ ). Therefore, the position of the main ceria band in the Raman spectra (see the detail of this band in Figure 6) suggests that the effect of $\mathrm{Nd}^{3+}$ doping prevails with respect to that of $\mathrm{Zr}^{4+}$ doping in all catalysts. Among the three catalysts studied, the higher displacement of the main Raman band below $465 \mathrm{~cm}^{-1}$ was obtained with the nitrates calcination catalyst, and this catalyst also presents the most intense vacant sites peak at $560 \mathrm{~cm}^{-1}$. These two experimental evidences are consistent to each other, because a suitable substitution of $\mathrm{Ce}^{4+}$ cations by $\mathrm{Nd}^{3+}$ cations occurs together with the creation of oxygen vacancies to compensate the charges imbalance. For the coprecipitation and microemulsion catalysts, the formation of the solid solutions is expected to be controlled by the solubility constants of the salts formed in alkali media. The solubility-product constants for $\mathrm{Ce}(\mathrm{OH})_{3}, \mathrm{Zr}(\mathrm{OH})_{4}$ and $\mathrm{Nd}(\mathrm{OH})_{3}$ are $1.5 \cdot 10^{-20}, 2 \cdot 10^{-48}$ and $5 \cdot 10^{-23}$, respectively [38, 39], and therefore, cerium and neodymium cations are expected to coprecipitate more homogeneously than zirconium cations, whose solubility is much lower.

In order to obtain additional information about the distribution of the different cations into the catalyst particles, chemical analyses of the catalyst particles surface was carried out by XPS, and the results obtained are compiled in Table 3. The surface carbon concentration is about 25 at. $\%$ for all catalysts due to atmospheric $\mathrm{CO}_{2}$ chemisorption. The ratio between the atomic fraction of cerium on the catalysts surface measured by XPS and the nominal cerium 


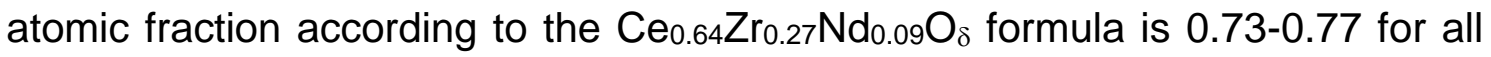
catalysts. This means that there is less cerium on the catalysts surface to that predicted by the general stoichiometry, since a value of 1 would be obtained if the surface and stoichiometric atomic fractions were equal. On the contrary, the ratio between surface and nominal zirconium is $1.83-1.89$ for all catalysts, evidencing that all catalysts present more zirconium on surface to that predicted by the stoichiometric formula. Minor differences are noticed in the cerium and zirconium surface/nominal ratios among the three catalysts studied. Nevertheless, differences are observed in the $\mathrm{Nd}$ ratios. The ratio between the atomic fraction of neodymium on the coprecipitation and microemulsion catalysts surface and the nominal atomic fraction is $0.18-0.19$, while this value increases to 0.29 for the nitrates calcination catalyst. Since all values are lower than 1 , it is deduced that there less neodymium on the catalysts surface to that predicted by stoichiometry, but the nitrates calcination catalyst has more neodymium on surface than the counterparts prepared by coprecipitation and microemulsion. This is consistent with the higher amount of oxygen vacant sites detected by Raman spectroscopy in the nitrates calcination catalyst and also with the highest shift of the main Raman band observed for this catalyst (see Figure 6). The differences observed in the cations distribution in the nitrates calcination catalyst with regard to the other two catalysts could be related to the fact that nitrates calcination is not affected by the solubility of the cationic species in water, as occurs for the coprecipitation and microemulsion methods.

In summary, the Raman spectroscopy and XPS characterization evidence that there is better introduction of $\mathrm{Nd}$ cations into the parent ceria framework for the catalyst prepared by nitrates calcination than for those 
prepared by microemulsion and coprecipitation, which promotes the creation of more oxygen vacancies. This would explain the high catalytic activity for soot combustion of the nitrates calcination catalyst, that is, $\mathrm{Nd}$ doping leads to the creation of a high amount of oxygen vacancies and this is expected to promote the exchange of oxygen with the gas molecules (mainly $\mathrm{NO}_{2}$ and $\mathrm{O}_{2}[1,40]$ ) which are responsible of the release of highly reactive oxygen species to soot.

Summing up all the experimental observations it can be concluded that the best catalytic performance of the microemulsion catalyst is related to its high surface area and low crystallite size, which improves the soot-catalyst contact and favors the transfer of active oxygen species from catalyst to soot. However, the nitrates calcination catalyst, which has not such high surface area, is able to nearly approach the catalytic activity of the microemulsion catalyst because $\mathrm{Nd}$ is loaded into the mixed oxide more efficiently. According to this conclusion, the future challenge would be to prepare high surface area Ce-Zr-Nd mixed oxides with proper $\mathrm{Nd}$ incorporation into the parent ceria lattice.

\section{4.- Conclusions.}

$\mathrm{Ce}_{0.64} \mathrm{Zr}_{0.27} \mathrm{Nd}_{0.09} \mathrm{O}_{\delta}$ mixed oxides have been prepared by nitrates calcination, coprecipitation and microemulsion, characterized and tested for soot combustion, and the main conclusions of the study can be summarized as follows:

- The catalyst prepared by microemulsion method is the most active, and the lowest activity was obtained with the catalyst prepared by coprecipitation. The catalyst prepared by nitrates precursors calcination is slightly less active to that prepared by microemulsion but the synthesis 
procedure is very straightforward and surfactants or other chemicals are not required, being very convenient for scaling up and practical utilization.

- The best catalytic performance of the microemulsion catalyst is related to its high surface area and low crystallite size.

- The high activity of the catalyst prepared by nitrates calcination can be attributed to the better introduction of $\mathrm{Nd}$ cations into the parent ceria framework, which promotes the creation of more oxygen vacancies.

\section{Acknowledgments}

The authors thank the Spanish Catalyst Society-SECAT for the grant of JGM and both the Spanish Ministry of Economy and Competitiveness and the FEDER funding of UE for the financial support to the Project CTQ2012-30703.

\section{References}

[1] A. Bueno-López, K. Krishna, M. Makkee, J. A. Moulijn, J. Catal. 230 (2005) 237-248.

[2] E. Aneggi, C. de Leitenburg, G. Dolcetti, A. Trovarelli, Catal. Today 114 (2006) 40-47.

[3] K. Krishna, A. Bueno-López, M. Makkee, J. A. Moulijn, Appl. Catal. B 75 (2007), 189-200.

[4] L. Katta, P. Sudarsanam, G. Thrimurthulu, B. M. Reddy, Appl. Catal. B 101 (2010) 101-108.

[5] P. Dulgheru, J. A. Sullivan, Top. Catal. 56 (2013) 504-510.

[6] I. Atribak, A. Bueno-López, A. García-García, J. Catal. 259 (2008) 123132.

[7] X. Wu, Q. Liang, D. Weng, Z. Lu, Z. Catal. Commun. 8 (2007) 21102114.

[8] M. Benjaram, B. Reddy, P. Bharali, G. Thrimurthulu, P. Saikia, L. Katta, S.-E. Park. Catal. Letters 123 (2008) 327-333. 
[9] F. Claudinei, F. Oliveira, F. A. C. Garcia, D. R. Araújo, J. L. Macedo, C. L. Sílvia Dias, José A. Dias. Appl. Catal. A 413-414 (2012) 292-300.

[10] E. Aneggi, C. de Leitenburg, J. Llorca, A. Trovarelli, Catal. Today 197 (2012) 119-126.

[11] V. Sánchez Escribano, E. Fernández López, J. M. Gallardo-Amores, C. del Hoyo Martínez, C. Pistarino, M. Panizza, C. Resini, G. Busca, (2008) Comb. Flame 153 (2012) 97-104

[12] C. A. Neyertz, E. D. Banús, E.E. Miró, E.E., C. A. Querini, Chem. Eng. J. 248 (2014) 394-405.

[13] Q. Liang, X. Wu, D. Weng, H. Xu, Catal. Today. 139 (2008) 113-118.

[14] X. Wu, F. Lin, H. Xu, D. Weng, Appl. Catal. B 96 (2010) 101-109.

[15] M. Fu, J. Lin, W. Zhu, W. U. Junliang, L. Chen, B. Huang, D. Ye, J. Rare Earths 32 (2014) 153-158.

[16] M. Casapu, A. Bernhard, D. Peitz, M. Mehring, M. Elsener, O. Kröcher, Appl. Catal. B 103 (2011) 79-84.

[17] A. M. Hernández-Giménez, L. P. dos Santos Xavier, A. Bueno-López, Appl. Catal. A 462-463 (2013) 100-106.

[18] M. Kurnatowska, W. Mista, P. Mazur, L. Kepinski, Appl. Catal. B 148-149 (2014) 123-135.

[19] L .F Nascimento, R. F. Martins, R.F. Silva, R.F., O. A. Serra, J. Env. Sci. (China) 26 (2014) 694-701.

[20] D. N. Durgasri, T. Vinodkumar, B. M. Reddy, B.M. J. Chem. Sci. 126 (2014) 429-435

[21] J. Kasïpar, P. Fornasiero, M. Graziani, Catal. Today 50 (1999) 285-298.

[22] I. Atribak, A. Bueno-López, A. García-García, J. Molec. Catal. A 300 (2009) 103-110.

[23] Q. Wang, G. Li, B. Zhao, R. Zhou, J. Hazar. Mater. 189 (2011) 150-157.

[24] L. P. dos Santos Xavier, V. Rico-Pérez, A. M. Hernández-Giménez, D. Lozano-Castelló, A. Bueno-López, Appl. Catal. B 162 (2015) 412-419.

[25] D. Terribile, A. Trovarelli, J. Llorca, C. de Leitenburg, G. Dolcetti, Catal. Today 43 (1998) 79-88

[26] W. J. Stark, M. Maciejewski, L. Mädler, S. E. Pratsinis, S.E., Baiker, J. Catal. 220 (2003) 35-43.

[27] J. C. Yu, L. Zhang, J. Lin. (2003) J. Colloid Int. Sci. 260, 240-243. 
[28] M. Crocker, U. M. Graham, R. Gonzalez, G. Jacobs, E. Morris, A. M. Rubel, R. Andrews, J. Mater. Sci. 42 (2007) 3454-3464.

[29] C. Bozo, F. Gaillard, N., Guilhaume, Appl. Catal. A 220 (2001) 69-77.

[30] I. Atribak, A. Bueno-López, A. Garcia-Garcia, Catal. Commun. 9 (2008) 250-255.

[31] I. Atribak, A., Bueno-Lopez, A., Garcia-Garcia, Top. Catal. 52 (2009) 2088-2091.

[32] B.A.A.L. van Setten, J.M. Schouten, M. Makkee, J.A. Moulijn, Appl. Catal. B 28 (2000) 253-257.

[33] G. K. Williamson, W. H., Hall, Acta Metallurgica 1 (1953) 22-31.

[34] G. L. Markaryan, L. N. Ikryannikova, G. P. Muravieva, A. O. Turakulova, B. G. Kostyuk, E. V. Lunina, V. V., Lunin, E. Zhilinskaya, A., Aboukais, Colloids Surf. A 151 (1999) 435-447

[35] J. Kašpar, R. Di Monte, P. Fornasiero, M. Graziani, H. Bradshaw, C. Norman, Top. Catal. 16/17 (2001) 419.

[36] A. Mineshige, T. Taji, Y. Muroi, M. Kobune, S. Fujii, N. Nishi, M. Inaba, Z. Ogumi, Solid State Ionics 135 (2000) 481- 485.

[37] J. E. Spanier, R. D. Robinson, F. Zhang, S-W. Chan, I. P. Herman, Physic. Rev. B 64 (2001) 245407.

[38] L. R. Morss, C. M. Haar, S. Mroczkowski, S. J. Chem. Thermod. 21 (1989) 1079-1083.

[39] Y. Guo, G. Lu, Z. Zhang, S. Zang, Y. Qi, Y. Liu, Catal. Today 126 (2007) 296-302.

[40] N. Guillén-Hurtado, A. García-García, A. Bueno-López, J. Catal. (2013) 299, 181-187. 
Table 1. $\mathrm{CO}_{2}$ yield with regard to total $\mathrm{COx}$ released as soot combustion product in experiments performed with $500 \mathrm{ppm} \mathrm{NO}+5 \% \mathrm{O}_{2}+\mathrm{N}_{2}$ (balance). Soot-catalyst mixtures were prepared in loose contact mode. (GHSV: $30000 \mathrm{~h}^{-1}$ ). Soot conversion profiles are shown in Figure 1.

\begin{tabular}{lc}
\hline Catalyst & $\mathrm{CO}_{2}$ yield (\%) \\
\hline None & 36 \\
Coprecipitation & 93 \\
Nitrates calcination & 92 \\
Microemulsion & 93 \\
\hline
\end{tabular}

Table 2. Results of the $\mathrm{N}_{2}$ adsorption-desorption and XRD characterization of the catalysts.

\begin{tabular}{lccc}
\hline Catalysts synthesis method & $\begin{array}{c}\text { BET } \\
\left(\mathrm{m}^{2} / \mathrm{g}\right)\end{array}$ & $\begin{array}{c}\text { Cell parameter } \\
(\mathrm{nm})^{\star}\end{array}$ & $\begin{array}{c}\text { Crystallite size } \\
\text { from W-H eq. } \\
(\mathrm{nm})\end{array}$ \\
\hline Coprecipitation & 74 & 0.5401 & 9 \\
Nitrates calcination & 70 & 0.5420 & 37 \\
Microemulsion & 147 & 0.5365 & 6 \\
\hline
\end{tabular}

*The experimental error is estimated to be $\pm 0.0025 \mathrm{~nm}$ 
Table 3. Surface characterization of the $\mathrm{Ce}_{0.64} \mathrm{Zr}_{0.27} \mathrm{Nd}_{0.09} \mathrm{O}_{\delta}$ catalysts carried out by XPS.

\begin{tabular}{|l|c|c|c|c|c|c|c|c|c|c|}
\hline Catalyst & $\begin{array}{c}\mathrm{Ce}^{3+} \\
(\text { at. \%) }\end{array}$ & $\begin{array}{c}\mathrm{Ce} \\
(\text { at.\%) }\end{array}$ & $\begin{array}{c}\mathrm{Zr} \\
(\text { at.\%) }\end{array}$ & $\begin{array}{c}\mathrm{Nd} \\
(\text { at.\%) }\end{array}$ & $\begin{array}{c}\mathrm{O} \\
(\text { at.\%) }\end{array}$ & $\begin{array}{c}\mathrm{C} \\
(\text { at.\%) }\end{array}$ & $\begin{array}{c}\mathrm{Ce} \mathrm{xps} / \mathrm{Ce}_{\text {nominal }} \\
\text { (at. ratio) }\end{array}$ & $\begin{array}{c}\mathrm{Zr}_{\mathrm{xps}} / \mathrm{Zr}_{\text {nominal }} \\
\text { (at. ratio) }\end{array}$ & $\begin{array}{c}\mathrm{Nd}_{\mathrm{xps}} / \mathrm{Nd}_{\text {nominal }} \\
\text { (at. ratio) }\end{array}$ & $\begin{array}{c}\text { Surface cations } \\
\text { stoichiometry }\end{array}$ \\
\hline Coprecipitation & 37.5 & 12.44 & 13.40 & 0.42 & 49.41 & 24.33 & 0.74 & 1.89 & 0.18 & $\mathrm{Ce}_{0.474} \mathrm{Zr}_{0,510} \mathrm{Nd}_{0.016} \mathrm{O}_{\delta}$ \\
\hline Nitrates calcination & 40.2 & 12.70 & 13.87 & 0.71 & 47.45 & 25.27 & 0.73 & 1.88 & 0.29 & $\mathrm{Ce}_{0.465} \mathrm{Zr}_{0,508} \mathrm{Nd}_{0.026} \mathrm{O}_{\delta}$ \\
\hline Microemulsion & 37.5 & 13.26 & 13.35 & 0.47 & 47.96 & 24.96 & 0.77 & 1.83 & 0.19 & $\mathrm{Ce}_{0.490} \mathrm{Zr}_{0,493} \mathrm{Nd}_{0.017} \mathrm{O}_{\delta}$ \\
\hline
\end{tabular}




\section{Figure Captions}

Figure 1. Soot combustion experiments performed with 500 ppm NO $+5 \% \mathrm{O}_{2}+\mathrm{N}_{2}$ (balance). Soot-catalyst mixtures were prepared in loose contact mode. (GHSV: 30000 $\left.\mathrm{h}^{-1}\right)$.

Figure 2. $\mathrm{N}_{2}$ adsortion-desorption isotherms at $-196{ }^{\circ} \mathrm{C}$ of the $\mathrm{Ce}_{0.64} \mathrm{Zr}_{0.27} \mathrm{Nd}_{0.09} \mathrm{O}_{2}$ catalysts.

Figure 3. Pore size distribution of the $\mathrm{Ce}_{0.64} \mathrm{Zr}_{0.27} \mathrm{Nd}_{0.09} \mathrm{O}_{\delta}$ catalysts determined by the BJH method.

Figure 4. X-Ray difractograms of the $\mathrm{Ce}_{0.64} \mathrm{Zr}_{0.27} \mathrm{Nd}_{0.09} \mathrm{O}_{\delta}$ catalysts.

Figure 5. $\mathrm{H}_{2}$-TPR characterization of the $\mathrm{Ce}_{0.64} \mathrm{Zr}_{0.27} \mathrm{Nd}_{0.09} \mathrm{O}_{\delta}$ catalysts.

Figure 6. Raman spectroscopy characterization of the $\mathrm{Ce}_{0.64} \mathrm{Zr}_{0.27} \mathrm{Nd}_{0.09} \mathrm{O}_{\delta}$ catalysts (signal intensity was normalized for the same intensity of the $\mathrm{F} 2 \mathrm{~g}$ peak at $\sim 465 \mathrm{~cm}^{-1}$ ). 


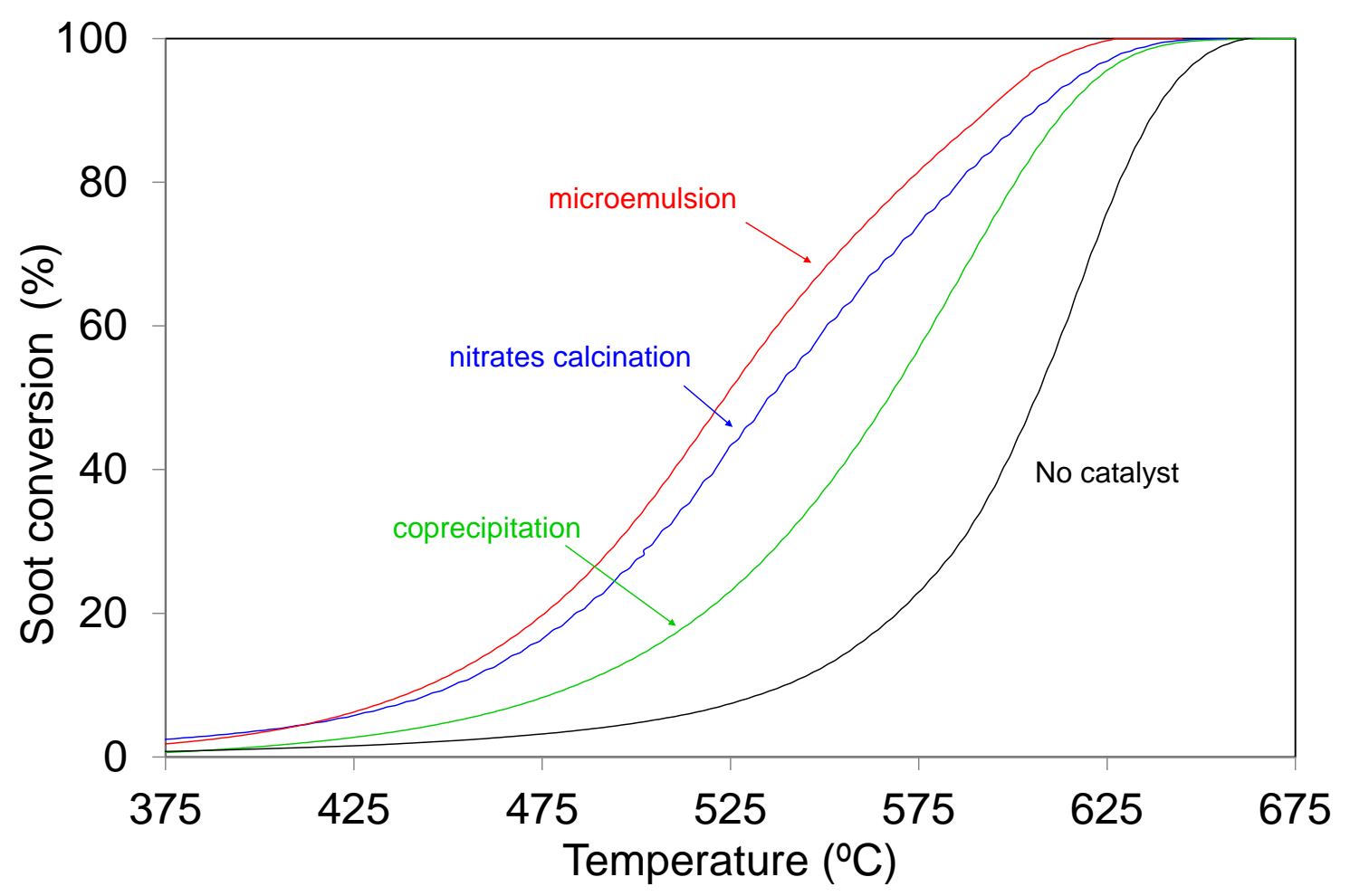

Figure 1. 


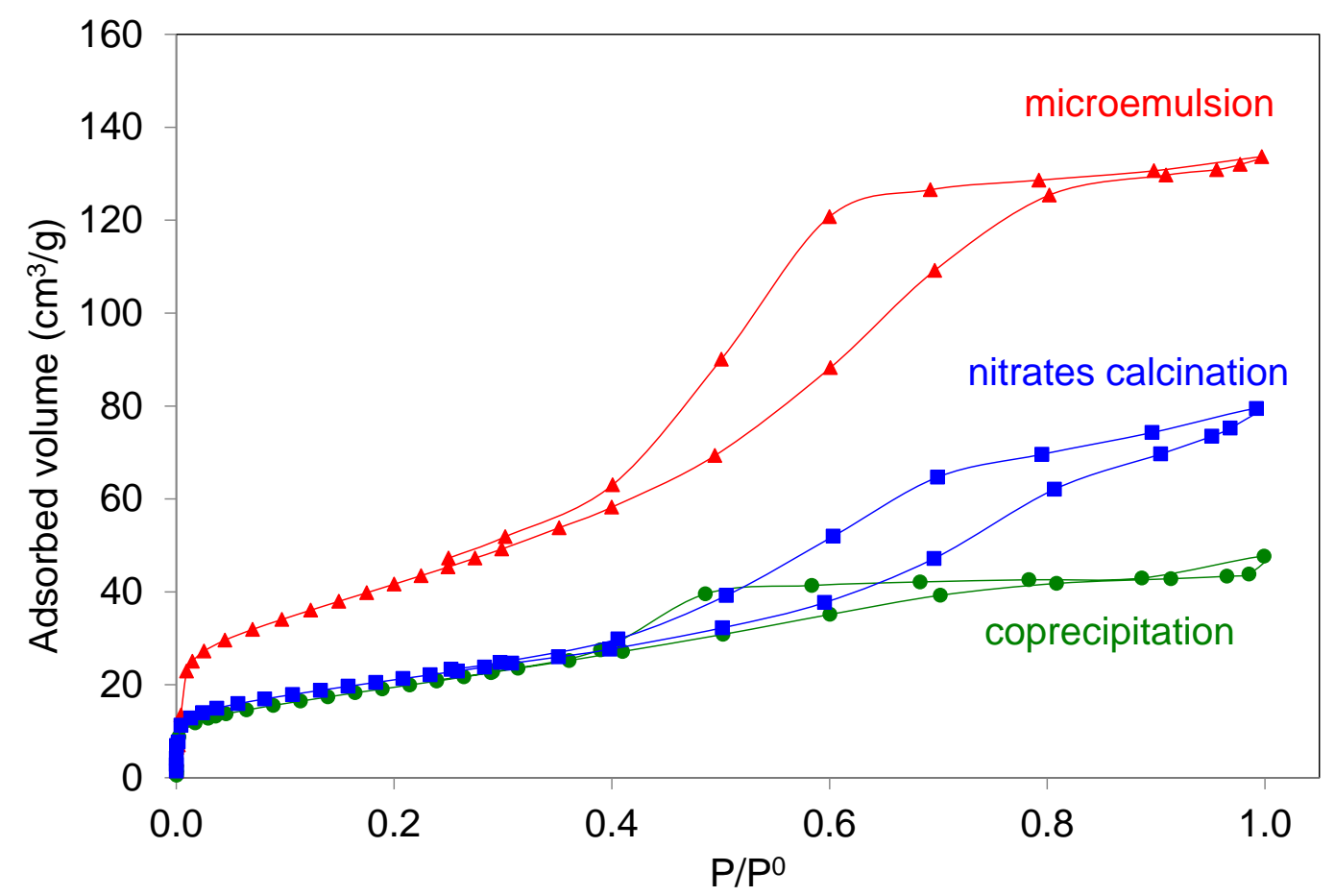

Figure 2. 


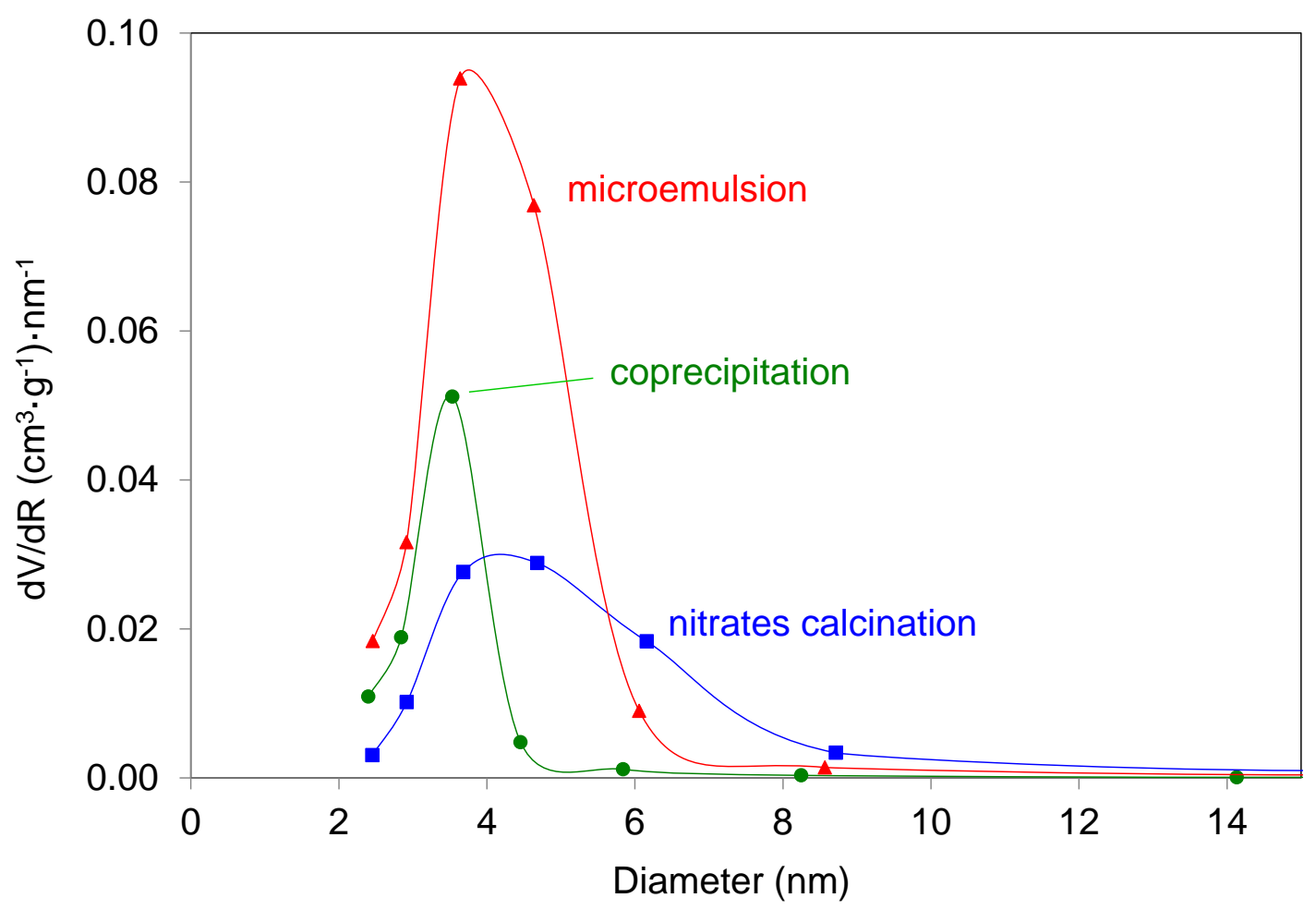

Figure 3 


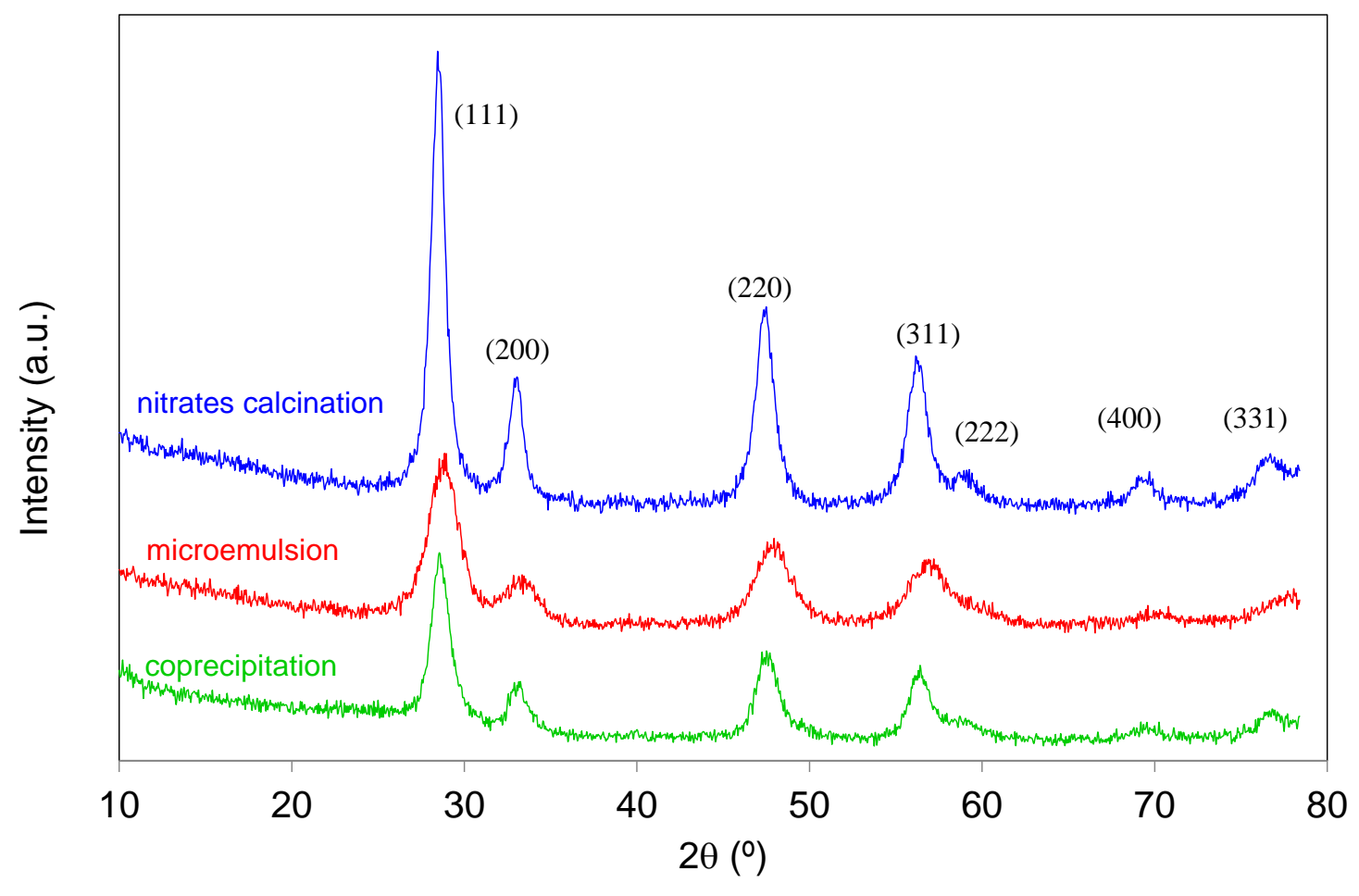

Figure 4. 


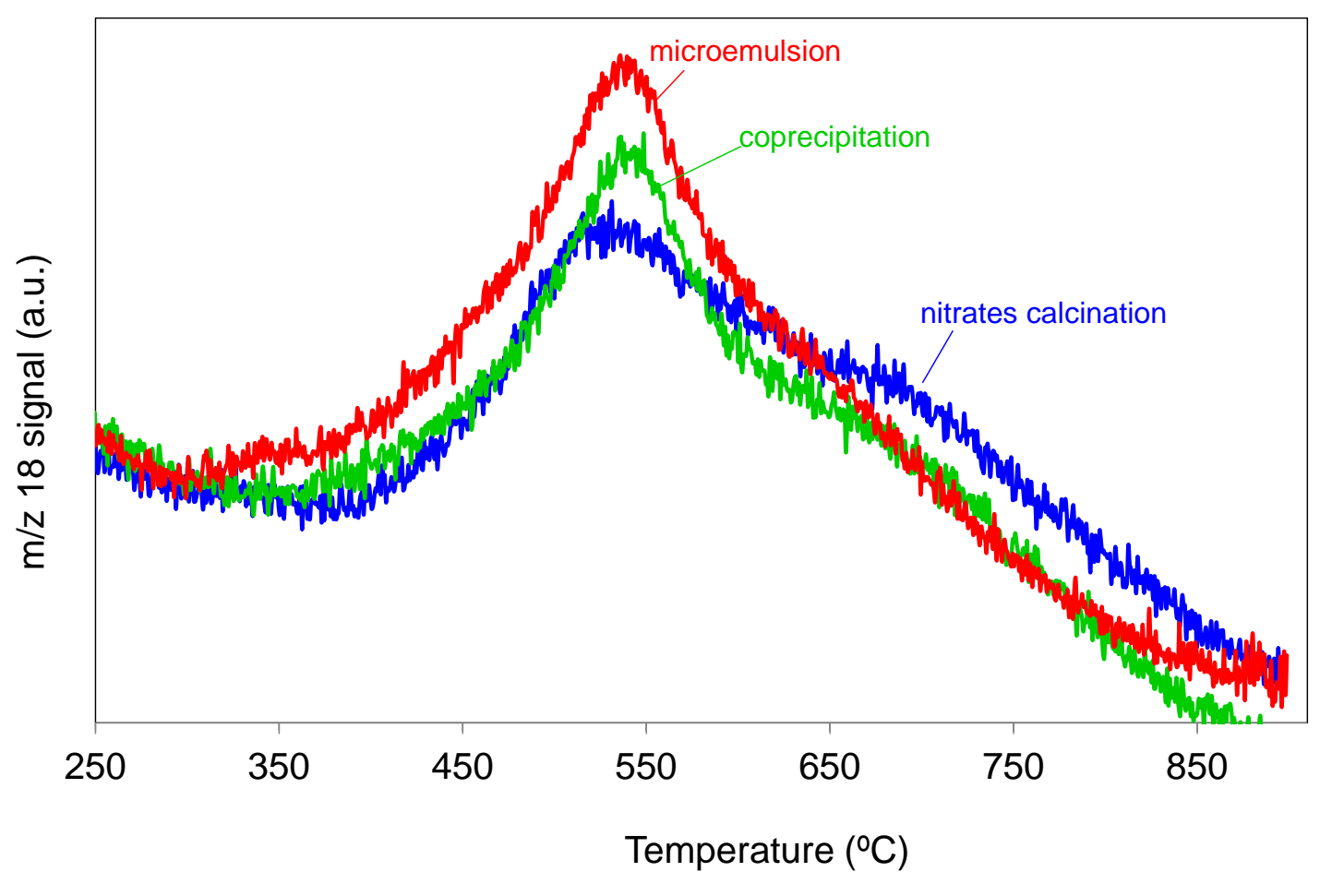

Figure 5. 


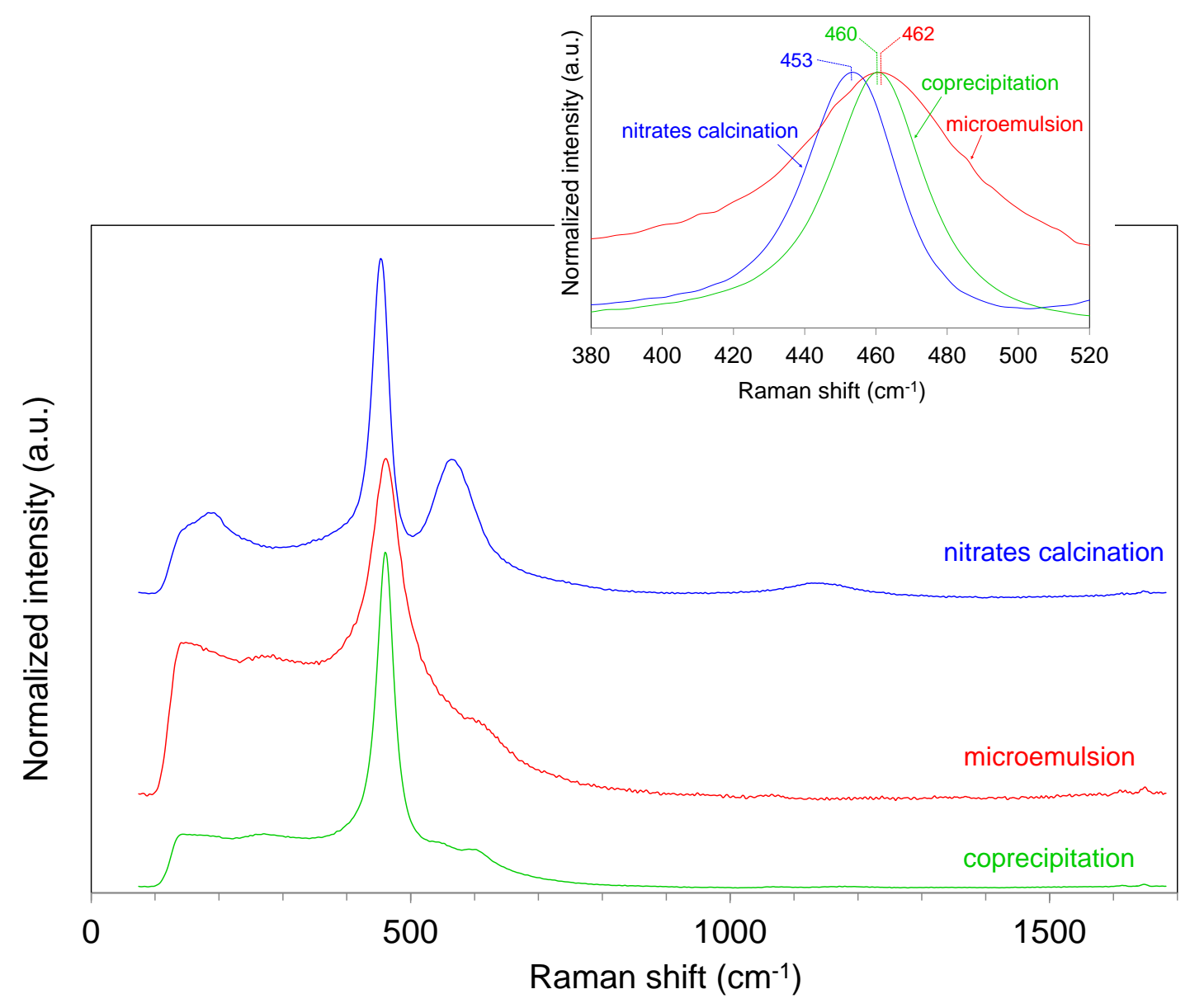

Figure 6. 